\title{
Mg-Cr Layered Double Hydroxide with Intercalated Oxalic Anion for Removal Cationic Dyes Rhodamine $B$ and Methylene Blue
}

\author{
Arini Fousty Badri ${ }^{1}$, Neza Rahayu Palapa ${ }^{1}$, Risfidian Mohadi ${ }^{2}$, Mardiyanto ${ }^{3}$, Aldes Lesbani $^{*}$ \\ ${ }^{1}$ Department of Chemistry, Faculty of Mathematics and Natural Sciences, Sriwijaya University, Jl. Palembang-Prabumulih, Km. 32, Ogan Ilir, South \\ Sumatra, Indonesia \\ ${ }^{2}$ Department of Environmental Science, Graduate School, Sriwijaya University, Jl. Padang Selasa No. 524 Ilir Barat 1, Palembang-South Sumatra, Indonesia \\ ${ }^{3}$ Department of Pharmacy, Faculty of Mathematics and Natural Sciences, Sriwijaya University, Jl. Jl. Palembang-Prabumulih, Km. 32, Ogan Ilir 30662, \\ South Sumatra, Indonesia
}

Received: 12/09/2020

Accepted: $13 / 12 / 2020$

Published: 20/06/2021

\begin{abstract}
A MgCr-based layered double hydroxide (LDH) was synthesized by a coprecipitation method, followed by an intercalation process using an oxalic anion. The materials were characterized using X-ray diffraction analysis, FT-IR spectroscopy, and $\mathrm{pH}$ pzc measurement. The materials were then applied as adsorbents for removal of methylene blue (MB) and rhodamine B (RhB) from aqueous solution. Pristine $\mathrm{Mg} / \mathrm{Cr} \mathrm{LDH}$ exhibited $\mathrm{RhB}$ adsorption capacity of $32.154 \mathrm{mg} \mathrm{g}^{-1}$, whereas the use of intercalated $\mathrm{Mg} / \mathrm{Cr} \mathrm{LDH}$ caused an increase in the capacity (139.526 $\mathrm{mg} \mathrm{g}^{-1}$ ). Kinetic studies indicated that the dye adsorption using both LDHs followed a pseudo-second-order kinetic model; the $K_{2}$ values of pristine and modified $\mathrm{Mg} / \mathrm{Cr} \mathrm{LDH}$ for $\mathrm{RhB}$ and $\mathrm{MB}$ were $6.970,0.001,0.426$, and $2.056 \mathrm{~g} \mathrm{mg}^{-1} \mathrm{~min}^{-1}$, respectively. The thermodynamic study identified that the adsorption of both dyes onto the LDHs was a spontaneous process and can be classified as physical adsorption with adsorption energies of $<40 \mathrm{~kJ} / \mathrm{mol}$. Moreover, the desorption and regeneration experiments indicated the high economic feasibility and reusability of the LDHs. By using $\mathrm{HCl}$ as the optimal solvent, the LDHs could desorb as much as $98 \%$ of the dye and could be used as adsorbents with high adsorption capacity over three cycles.
\end{abstract}

Keywords: Layered double hydroxide, $\mathrm{MgCr}$, rhodamine B, methylene blue, intercalation

\section{Introduction}

The contamination of water bodies due to dyes negatively affects the ecological system and human health [1]. Industrial activities such as production of textile, paper, and rubber use reactive synthetic dyes [2,3]. Such dyes are harmful organic pollutants because of their carcinogenic effects [3-5]. Dye contaminants are synthetic dyes that are non-biodegradable; therefore, it is recommended to remove such pollutants from wastewater before being discharged into natural water [6]. Several methods have been employed to remove dyes from wastewater, such as ion exchange, filtration, membrane separation, electrochemical degradation, and adsorption methods. Among these methods, adsorption is a suitable method to remove dyes from wastewater because of its low cost and high efficiency and because it involves a simple treatment. Moreover, adsorption efficiency depends on the adsorbent $[7,8]$.

Various adsorbents have been used to remove dyes from wastewater such as bentonite [9], kaoline, activated carbon, zeolites, and hydrotalcite [10-12]. Hydrotalcite is a class of clay materials and serves as effective sorbents [13,14]. However, to achieve high efficiency for dye adsorption, hydrotalcite must be modified using an intercalating process with organic [15] or inorganic anions to increase its surface area [16]. Hydrotalcites have been extensively modified to impart high adsorption capacity and efficiency; such modification methods include development of $\mathrm{LDH}-\mathrm{MnFe}_{2} \mathrm{O}_{4}$ hybrid materials [17] and intercalation of LDHs with aromatic acid anions [18].

Anionic synthetic clay layered double hydroxides (LDHs) consist of divalent and trivalent brucite-like layers that have a positive charge and an anion functioning as a counterion. These compounds have a general formula of $\left[\mathrm{M}_{(1-\mathrm{II})}^{\mathrm{II}} \mathrm{M}^{\mathrm{III}}{ }_{\mathrm{x}}\right.$ $\left.(\mathrm{OH})_{2}\right]^{\mathrm{x}+}\left(\mathrm{An}^{-}\right)^{\mathrm{x} / \mathrm{n}} \cdot \mathrm{mH}_{2} \mathrm{O}$, where $\mathrm{An}^{-}$is the intercalated anion [1921]. The anion in the interlayer of the $\mathrm{LDH}$ can be replaced, under suitable conditions, with inorganic ions such as nitrate, carbonate [22], and sulfate ions in order to enhance the interlayer. Modified LDHs have applications in various fields, especially in dye removal. According to Santos et al., calcined LDH was used to adsorb acid yellow 42 in aqueous solutions [23]. Deng et al. [24]

Corresponding author: Aldes Lesbani, Department of Chemistry, Faculty of Mathematics and Natural Sciences, Sriwijaya University, Jl. Palembang-Prabumulih, Km. 32, Ogan Ilir, South Sumatra, Indonesia. E-mail: aldeslesbani@pps.unsri.ac.id 
reported the use of sodium-dodecyl-sulfate-intercalated and acrylamide-anchored LDH for the removal of Congo red. In contrast, $\mathrm{Xu}$ et al. prepared polyoxometalate-intercalated $\mathrm{ZnAlFe}$ $\mathrm{LDH}$, which exhibited improved adsorption capacity for cationic dye removal [14]. Similarly, Li et al. used a magnetic core-shell dodecyl-sulfate-intercalated $\mathrm{LDH}$ nanocomposite to adsorb cationic and anionic organic dyes [25].

In this study, $\mathrm{Mg} / \mathrm{Cr} \mathrm{LDH}$ was synthesized by a coprecipitation method. The LDH was modified by intercalating oxalate anions $\left(\mathrm{C}_{2} \mathrm{O}_{4}{ }^{2-}\right)$ into the interlayer space of hydrotalcite via anion exchange. The pristine and intercalated LDHs were then applied as adsorbents for removal of rhodamine $\mathrm{B}(\mathrm{RhB})$ and methylene blue (MB). The structures of these dyes are presented in Fig. 1. The adsorption of the dyes using the intercalated LDH material was then optimized by varying the contact time, initial concentration, and temperature. A desorption process was conducted to determine a suitable solvent using several organic solvents, followed by regeneration over three cycles.
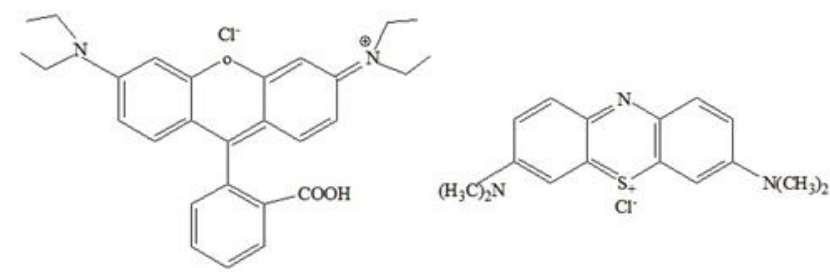

(a)

(b)

Figure 1: Structures of (a) rhodamine B and (b) methylene blue

\section{Materials and Methods}

The chemicals used in this study were $\mathrm{Mg}\left(\mathrm{NO}_{3}\right)_{2} \cdot 6 \mathrm{H}_{2} \mathrm{O}$ (Sigma-Aldrich, $\quad 400.15 \mathrm{~g} / \mathrm{mol}$ ), $\quad \mathrm{Cr}\left(\mathrm{NO}_{3}\right)_{3} \cdot 9 \mathrm{H}_{2} \mathrm{O}$ (EMSURE $^{\circledR}$ ACS, Reag. Ph Eur, $256.41 \mathrm{~g} / \mathrm{mol}$ ), $\mathrm{Na}_{2} \mathrm{CO}_{3}$ (EMSURE $^{\circledR}$ ACS, Reag. Ph Eur, $126.07 \mathrm{~g} / \mathrm{mol}$ ), $\mathrm{NaOH}$ (EMSURE $^{\circledR}$ ACS, Reag. $\quad \mathrm{Ph}$ Eur, $40 \mathrm{~g} / \mathrm{mol}$ ), $\mathrm{HCl}$ (MallinckrodtAR ${ }^{\circledR}, 37 \%$ ), and $\mathrm{H}_{2} \mathrm{C}_{2} \mathrm{O}_{4} \cdot 2 \mathrm{H}_{2} \mathrm{O}$ (EMSURE ${ }^{\circledR}$ ACS, Reag. Ph Eur, $126.07 \mathrm{~g} / \mathrm{mol}$ ). All chemicals were used as received without further purification. X-ray diffraction (XRD) analysis was performed using a Rigaku Miniflex-6000 diffractometer, and the sample was scanned at $10 \% \mathrm{~min}$ The Brunauer-Emmett-Teller (BET) surface area was measured using a Quantachrome adsorption-desorption apparatus. The sample was degassed prior to analysis at $77 \mathrm{~K}$. Fourier transform infrared (FT-IR) spectroscopy was performed using a Shimadzu Prestige-21 device, with the use of $\mathrm{KBr}$ pellets; each sample was analyzed at wavenumbers in the range of $400-4000 \mathrm{~cm}^{-1}$. The concentrations of the dyes were measured using a Biobase BK 1800 UV-Visible spectrophotometer.

\subsection{Synthesis $\mathrm{Mg} / \mathrm{Cr} \mathrm{LDH}$}

$\mathrm{Mg} / \mathrm{Cr} \mathrm{LDH}$ was synthesized by a coprecipitation method. First, a solution of $\mathrm{Mg}\left(\mathrm{NO}_{3}\right)_{2} \cdot 6 \mathrm{H}_{2} \mathrm{O}$ was mixed with $\mathrm{Cr}\left(\mathrm{NO}_{3}\right)_{3} \cdot 9 \mathrm{H}_{2} \mathrm{O}$ (3:1) and stirred for $30 \mathrm{~min}$. A solution of $\mathrm{Na}_{2} \mathrm{CO}_{3}(1 \mathrm{M})$ and $\mathrm{NaOH}(2 \mathrm{M})$ was added to the reaction mixture. The mixture was then mixed under continuous stirring until a precipitate was formed, and then the $\mathrm{pH}$ of the solution was adjusted to 10 using $\mathrm{NaOH}$. The reaction was maintained at $80{ }^{\circ} \mathrm{C}$ for $24 \mathrm{~h}$ to produce $\mathrm{Mg} / \mathrm{Cr} \mathrm{LDH}$. The solid material was then heated at $80{ }^{\circ} \mathrm{C}$ for $24 \mathrm{~h}$.

\subsection{Intercalation of $\mathrm{Mg} / \mathrm{Cr} \mathrm{LDH}$ with Oxalic Anion}

$\mathrm{Mg} / \mathrm{Cr} \mathrm{LDH}$ intercalated with oxalic anions was prepared by the ion-exchange method. As much as $50 \mathrm{~g}$ of $\mathrm{Mg} / \mathrm{Cr} \mathrm{LDH}$ was mixed with water, and the solution was stirred for $60 \mathrm{~min}$ under a nitrogen atmosphere. The LDH mixture was then added to a solution of oxalic acid. The $\mathrm{pH}$ of the mixture was adjusted to 9 using $\mathrm{NaOH}$. The suspension was stirred for $24 \mathrm{~h}$ under a $\mathrm{N}_{2}$ atmosphere and dried at $100{ }^{\circ} \mathrm{C}$.

\subsection{Adsorption of Methylene Blue and Rhodamine $B$ using $\mathrm{Mg} / \mathrm{Cr} \mathrm{LDH}$ and Intercalated $\mathrm{Mg} / \mathrm{Cr} \mathrm{LDH}$}

First, $0.02 \mathrm{~g}$ of $\mathrm{LDH}$ was added to $20 \mathrm{~mL}$ of $\mathrm{MB}$ and $\mathrm{RhB}$, each having a concentration of $70 \mathrm{mg} / \mathrm{L}$. The adsorption studies were carried out under stirring over different durations (5-120 min). After stirring, the suspensions were separated by centrifugation at $3000 \mathrm{rpm}$ for $10 \mathrm{~min}$ and examined via UV-Vis spectrophotometry at $662 \mathrm{~nm}$ for methylene blue and $555 \mathrm{~nm}$ for rhodamine B. After equilibrium was reached, $0.5 \mathrm{~g}$ of $\mathrm{LDH}$ was used to adsorb the dyes at different dye concentrations (10-60 $\mathrm{mg} / \mathrm{L})$ and temperatures (303-333 K).

\subsection{Desorption and Regeneration of Methylene Blue and} Rhodamine B using $\mathrm{Mg} / \mathrm{Cr} \mathrm{LDH}$ and Intercalated $\mathrm{Mg} / \mathrm{Cr} \mathrm{LDH}$

A desorption process was performed to examine the efficiency of the adsorbent. First, $0.5 \mathrm{~g}$ of $\mathrm{LDH}$ was added to $50 \mathrm{~mL}$ of $\mathrm{MB}$ and $\mathrm{RhB}(100 \mathrm{ppm})$ and shaken for $120 \mathrm{~min}$. Then, the dye concentration in the filtrate was determined by UV-Vis spectrophotometry, followed by drying of the adsorbent for $2 \mathrm{~h}$. The residue $(0.01 \mathrm{~g})$ was shaken in $10 \mathrm{~mL}$ solvent $(\mathrm{HCl}, \mathrm{NaOH}$, hydroxylamine hydrochloride, water, and Na-EDTA) for 120 min. The filtrate was examined via UV-Vis spectrophotometry. The regeneration process was carried out using three cycles of the adsorption-desorption process.

\section{Results and Discussion}

The diffraction patterns of the pristine and modified $\mathrm{Mg} / \mathrm{Cr}$ LDHs are shown in Fig. 2. The diffractogram of the pristine $\mathrm{Mg} / \mathrm{Cr} \mathrm{LDH}$ (Fig. 2a) consisted of both sharp and symmetrical peaks and some high-intensity asymmetrical peaks. This result explains the highly crystalline and ordered layered structure of $\mathrm{Mg} / \mathrm{Cr} \mathrm{LDH}$. The typical pattern corresponding to hydrotalcite is evident, which is a set of four reflection lines at $2 \theta=11^{\circ}, 22^{\circ}$, $36^{\circ}$, and $60^{\circ}$ that are ascribed to the reflections of the (003), (006), (115), and (110) basal planes, respectively. The interlayer distance of the pristine LDH was $7.62 \AA$ (Fig. 2a). The XRD pattern of $\mathrm{Mg} / \mathrm{Cr}$-oxalate $\mathrm{LDH}$ exhibits a lower intensity than that before intercalation, indicating a decrease in the crystallinity of the LDH interlayer due to the presence of oxalate (Fig. 2b). The (003) reflection suggests that the reflection shifted to lower angles which indicated an increase in the basal spacing of $\mathrm{Mg} / \mathrm{Cr}$-oxalate LDH $(11.35 \AA)$. The peak shift from $2 \theta=11^{\circ}$ to $10^{\circ}$ indicates the replacement of nitrate ions with oxalate ions in the interlayer. Hence, the intercalation process with the oxalate anion was successful, and significant interlayer separation was achieved. 


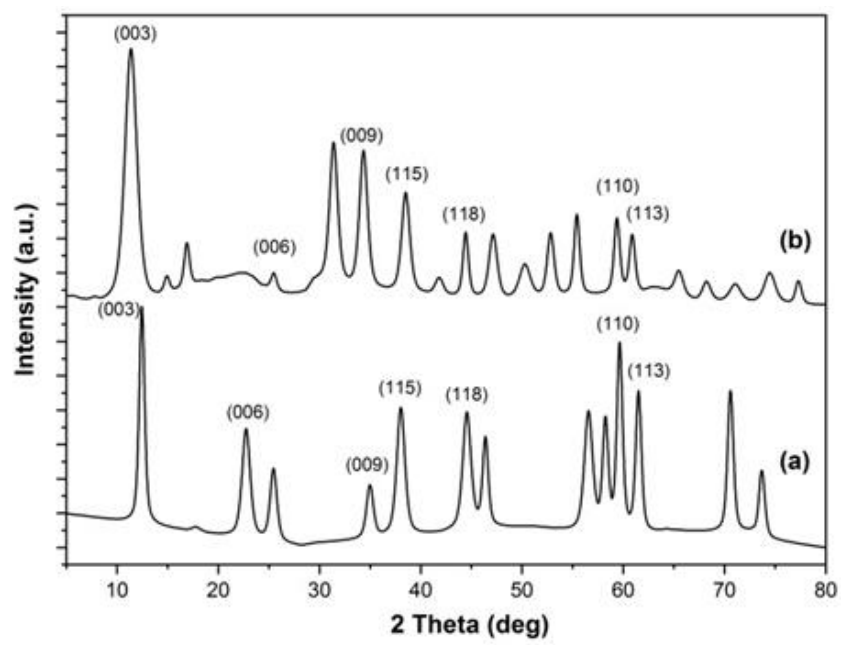

Figure 2: X-ray Powder diffraction patterns of $\mathrm{Mg} / \mathrm{Cr} \mathrm{LDH}$ (a) and intercalated $\mathrm{Mg} / \mathrm{Cr} \mathrm{LDH}(\mathrm{b})$

Figs. $3 a$ and $b$ show the graphs of the BET curves of $\mathrm{Mg} / \mathrm{Cr}$ $\mathrm{LDH}$ and intercalated $\mathrm{Mg} / \mathrm{Cr} \mathrm{LDH}$; these graphs indicated that both materials followed type IV isotherm patterns according to IUPAC classifications and that the materials were mesoporous; occurrence of hysteresis was also confirmed. The materials $\mathrm{Mg} / \mathrm{Cr}$ and intercalated $\mathrm{Mg} / \mathrm{Cr} \mathrm{LDH}$ contained mesopores that were $2-50 \mathrm{~nm}$ in size, based on IUPAC classifications. The isotherms of both $\mathrm{Mg} / \mathrm{Cr} \mathrm{LDH}$ and intercalated $\mathrm{Mg} / \mathrm{Cr} \mathrm{LDH}$ were ascribed to type $\mathrm{H} 2$ because the material contained large mesopores [26]. Table 1 summarizes the surface areas and pore sizes of $\mathrm{Mg} / \mathrm{Cr} \mathrm{LDH}$ and intercalated $\mathrm{Mg} / \mathrm{Cr} \mathrm{LDH}$. The results indicated an increase in the surface area by as much as 26.1153 $\mathrm{m}^{2} / \mathrm{g}$ after intercalation, which resulted in a decrease in the pore diameter of the LDH.

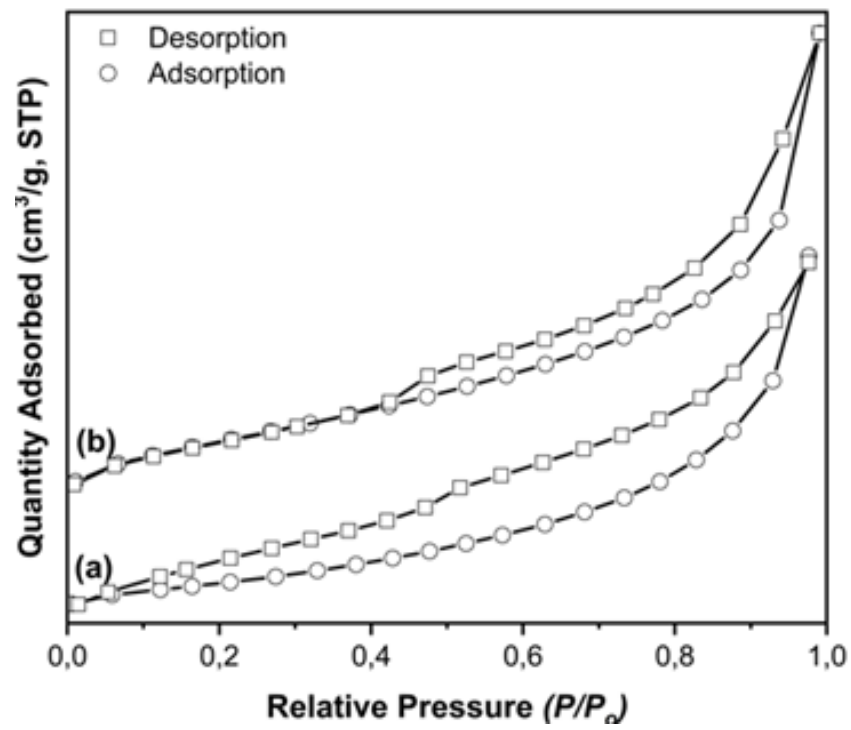

Figure 3: $\mathrm{N}_{2}$ Adsorption-desorption of $\mathrm{Mg} / \mathrm{Cr} \mathrm{LDH}$ (a) and intercalated $\mathrm{Mg} / \mathrm{Cr} \mathrm{LDH}$ (b)

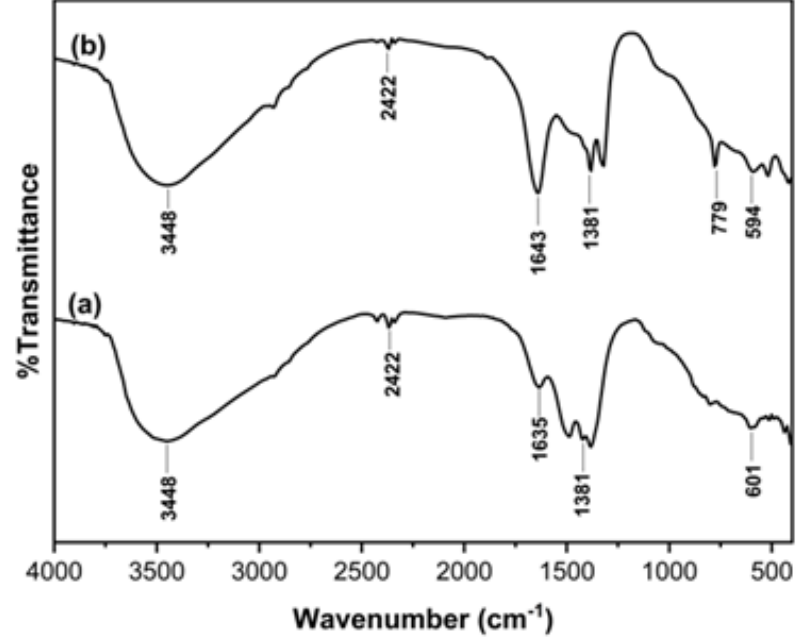

Figure 4: FT-IR spectra of $\mathrm{Mg} / \mathrm{Cr} \mathrm{LDH}$ (a) and intercalated $\mathrm{Mg} / \mathrm{Cr} \mathrm{LDH}$

(b)

Fig. 4 presents the FT-IR spectra of the materials. All samples exhibited broad bands at around $3400 \mathrm{~cm}^{-1}$, indicating the presence of an $\mathrm{OH}$ group. This band may be attributed to the hydroxyl group of water molecules, and the interlayer anions could also account for the broadening of this band. The bending mode of water gave rise to a rather weak band around $1635 \mathrm{~cm}^{-1}$ in the FT-IR spectra of $\mathrm{Mg} / \mathrm{Cr} \mathrm{LDH}$ (Fig. 4a). The vibrational modes of the interlayer nitrate ions are indicated by the peak at $1381 \mathrm{~cm}^{-1}$. This spectrum is observed for every hydroxide irrespective of nature. The octahedral sheets suggest a rather symmetric environment for the interlayer anions. The absorption peaks below $1000 \mathrm{~cm}^{-1}$ correspond to $\mathrm{M}-\mathrm{O}$ and $\mathrm{M}-\mathrm{O}-\mathrm{M}$ vibrations. The presence of oxalate anions in the LDH was confirmed by the presence of a peak at $1381 \mathrm{~cm}^{-1}$ (Fig. 4b), which could be assigned to the stretching modes of the carboxylate group.

Furthermore, the relatively weak peaks at 779 and $594 \mathrm{~cm}^{-1}$ correspond to the carbon-oxygen bond in the carboxyl group [27]. In addition, the strong absorption peak of the nitrate anions in Fig. 4a decreased after the ion-exchange reaction (Fig. 4b). This result indicated that oxalate anions replaced the interlamellar nitrate anions, as previously evidenced by X-ray analysis.

The stabilities of the pristine and modified LDHs were determined by $\mathrm{pH}$ point zero charges (pzc), as shown in Fig. 5. The pristine and modified LDHs prior to use as dye adsorbents were examined using $\mathrm{pH}$ pzc to determine the charge of the materials. As shown in Fig. 5, the cross point was identified at $\mathrm{pH}$ 9 for both pristine and modified LDHs. A pH of 9 was ascribed to the material when it has no charge. As such, the materials have positive charges below $\mathrm{pH} 9$ and negative charges above $\mathrm{pH} 9$. 


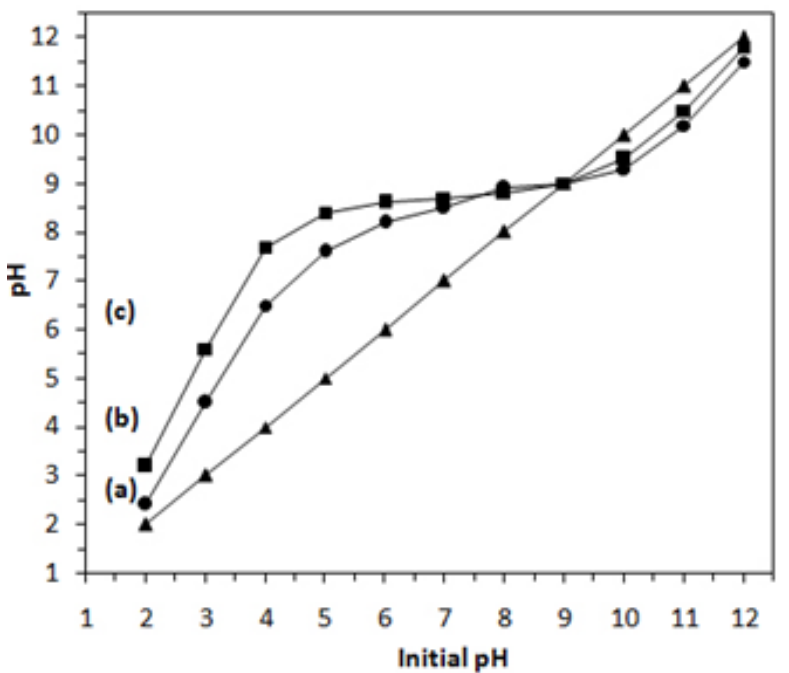

Figure 5: pH pzc graphs of $\mathrm{Mg} / \mathrm{Cr} \mathrm{LDH}$ (a) and intercalated $\mathrm{Mg} / \mathrm{Cr} \mathrm{LDH}$ (b)

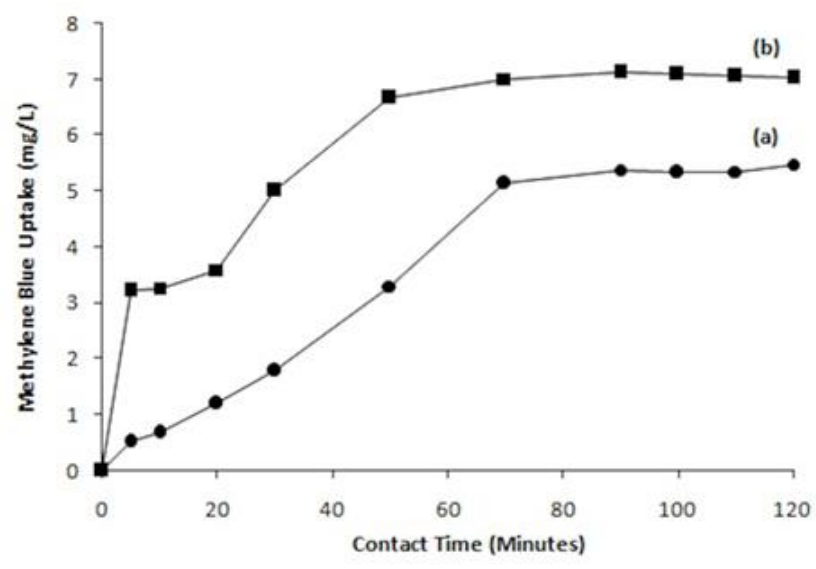

Figure 6: Time variation of adsorption of methylene blue on $\mathrm{Mg} / \mathrm{Cr}$ $\mathrm{LDH}$ (a) and intercalated $\mathrm{Mg} / \mathrm{Cr} \mathrm{LDH}$ (b)

The results of the adsorption of $\mathrm{MB}$ by $\mathrm{MgCr} \mathrm{LDH}$ and $\mathrm{MgCrC}_{2} \mathrm{O}_{4}^{-} \mathrm{LDH}$, which was conducted at $\mathrm{pH} 9$, are shown in Fig. 6 . The adsorption equilibrium was reached after $70 \mathrm{~min}$ with a MB uptake of $4.9 \mathrm{mg} / \mathrm{L}$ for pristine $\mathrm{LDH}$ and $6.5 \mathrm{mg} / \mathrm{L}$ for the modified LDH. This contact time was considered optimal for the next experiment. The adsorption of RhB using modified $\mathrm{LDH}$, as shown in Fig. 7, improved slightly and reached equilibrium after
70 min; equilibrium was reached after 20 min for pristine LDH The RhB uptake using the modified $\mathrm{Mg} / \mathrm{Cr} \mathrm{LDH}$ was twice that of pristine $\mathrm{Mg} / \mathrm{Cr} \mathrm{LDH}$, with each adsorbing $43 \mathrm{mg} / \mathrm{L}$ and 19 $\mathrm{mg} / \mathrm{L}$ of $\mathrm{RhB}$, respectively.

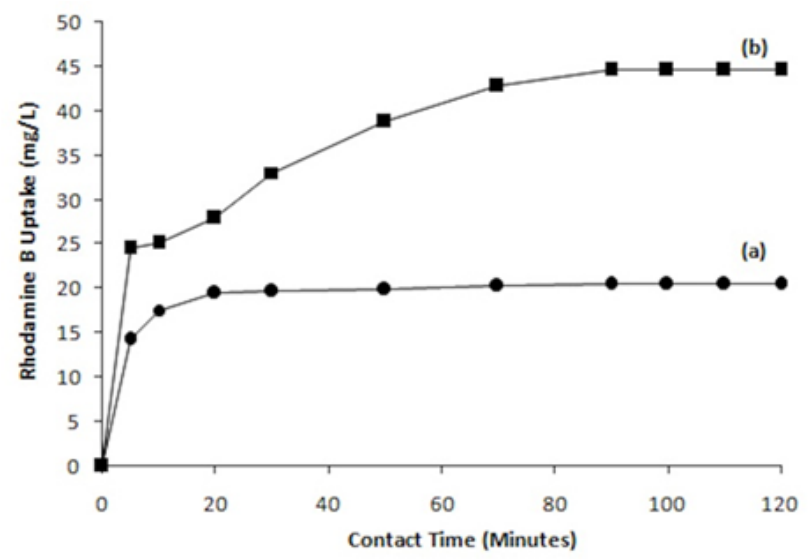

Figure 7: Time variation adsorption of rhodamine B on $\mathrm{Mg} / \mathrm{Cr} \mathrm{LDH}$ (a) and intercalated $\mathrm{Mg} / \mathrm{Cr} \mathrm{LDH}(\mathrm{b})$

The effect of contact time on the adsorption of dyes on pristine and modified $\mathrm{Mg} / \mathrm{Cr} \mathrm{LDHs}$ was shown in Fig. 8. The amount of dye adsorbed by LDHs notably increased with increasing contact time. However, the sorption rate of the dyes on the pristine LDH was slightly lower than that on the modified $\mathrm{LDH}$. The kinetics results indicate that the modified LDH exhibited a higher sorption efficiency for both dyes. Pseudo-firstorder and pseudo-second-order kinetic models were applied to determine the kinetic sorption process; such models are respectively expressed as follows:

$\ln \left(\mathrm{q}_{\mathrm{e}}-\mathrm{q}_{\mathrm{t}}\right)=\ln \mathrm{q}_{\mathrm{e}}-\mathrm{k}_{1} \mathrm{t}$

$\mathrm{t} / \mathrm{qt}=1 /\left(\mathrm{k}_{2} \mathrm{q}_{\mathrm{e}}^{2}\right)+\left(1 / \mathrm{q}_{\mathrm{e}}\right) \mathrm{t}$,

where $\mathrm{q}_{\mathrm{t}}(\mathrm{mg} / \mathrm{g})$ is the concentration of dye adsorbed at time $\mathrm{t}$ (min), $\mathrm{q}_{\mathrm{e}}(\mathrm{mg} / \mathrm{g})$ is the concentration of dye adsorbed at equilibrium, $\mathrm{k}_{1}$ is the rate constant of first-order sorption, and $\mathrm{k}_{2}$ is the rate constant of pseudo-second-order (PSO) sorption. The results of such calculations are shown in Table 2. This table shows that the sorption of the dyes on pristine LDH and modified LDH conform to the PSO kinetic model. The results suggest that interactions between the sorbate and sorbent were presented.

Table 2: Kinetic parameters of dyes adsorption onto $\mathrm{Mg} / \mathrm{Cr}-\mathrm{LDH}$ and intercalated $\mathrm{Mg} / \mathrm{Cr} \mathrm{LDH}$

\begin{tabular}{|c|c|c|c|c|c|c|c|c|}
\hline \multirow{2}{*}{$\mathrm{LDH}$} & & \multicolumn{4}{|c|}{ PFO } & \multicolumn{3}{|c|}{ PSO } \\
\hline & & $\mathrm{Co}(\mathrm{mg} / \mathrm{L})$ & qe $(\mathrm{mg} / \mathrm{g})$ & $\mathrm{K}_{1}\left(\min ^{-1}\right)$ & $\mathrm{R}^{2}$ & $\mathrm{qe}(\mathrm{mg} / \mathrm{g})$ & $\mathrm{K}_{2}\left(\mathrm{~g} \mathrm{mg} \mathrm{min}^{-1}\right)$ & $\mathrm{R}^{2}$ \\
\hline $\mathrm{Mg} / \mathrm{Cr}$ & Rh-B & 50 & 41.572 & 0.003 & 0.801 & 0.409 & 6.970 & 0.9878 \\
\hline $\mathrm{Mg} / \mathrm{Cr}$-oxalate & $\mathrm{Rh}-\mathrm{B}$ & 50 & 47.022 & 0.056 & 0.897 & 2.350 & 0.426 & 0.988 \\
\hline $\mathrm{Mg} / \mathrm{Cr}$ & MB & 10 & 7.786 & 0.040 & 0.935 & 10.225 & 0.001 & 0.940 \\
\hline $\mathrm{Mg} / \mathrm{Cr}$-oxalate & MB & 10 & 10.022 & 0.081 & 0.904 & 0.486 & 2.056 & 0.992 \\
\hline
\end{tabular}


The data on the effect of dye concentration and temperature, as shown in Figs. 8 and 9. It can be observed that increasing the concentration and temperature would increase the amount of dye adsorbed on both pristine and modified LDHs. There is a specific increase in the concentration of adsorbed RhB at $30 \mathrm{mg} / \mathrm{L}$ (Fig. $8 \mathrm{a}$ ), which is probably due to the physical adsorption of $\mathrm{RhB}$ as the interaction between the sorbate and sorbent was at equilibrium. The increasing trend for the adsorption isotherm of $\mathrm{RhB}$ on modified LDH was determined from the data in Fig. 8a using Langmuir and Freundlich equations. Fig. 8b exhibits a similar behavior for the adsorption of $\mathrm{RhB}$, which was at a concentration of $15 \mathrm{mg} / \mathrm{L}$, as observed for the curves with increasing temperature.
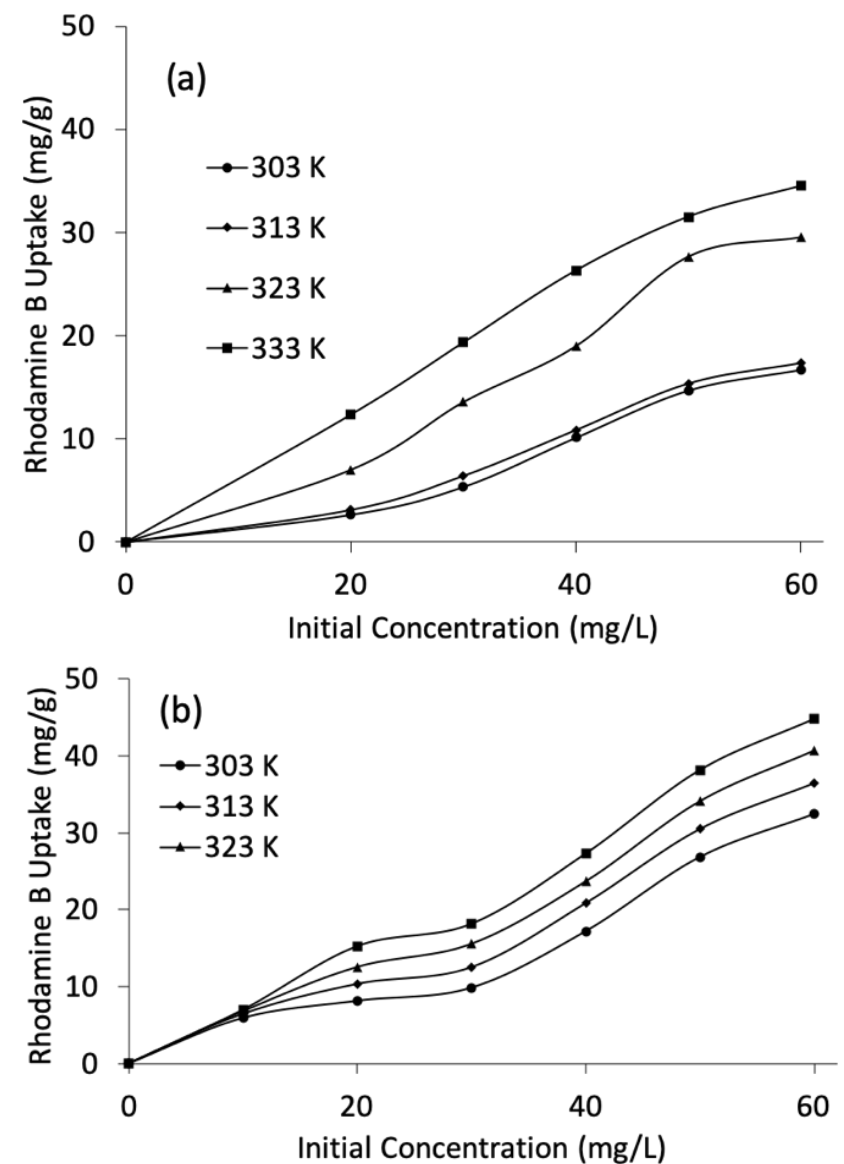

Figure 8: RhB uptake by initial concentration at various temperatures by $\mathrm{Mg} / \mathrm{Cr} \mathrm{LDH}$ (a) and intercalated $\mathrm{Mg} / \mathrm{Cr} \mathrm{LDH}$ (b)

The results of the adsorption of $\mathrm{MB}$ onto pristine $\mathrm{LDH}$ and modified LDH are shown in Fig. 9. For the adsorption of MB on both adsorbents, the difference in dye uptake at different temperatures was not significant. As shown in Fig. 9a, the adsorption rate of $\mathrm{MB}$ on pristine $\mathrm{LDH}$ was $23 \mathrm{mg} / \mathrm{g}$ at $333 \mathrm{~K}$, which indicated a higher adsorption capacity. Tables 3 and 4 summarize the isotherm parameters for the adsorption of the dyes on pristine $\mathrm{LDH}$ and modified LDH. The adsorption isotherm data for $\mathrm{RhB}$ is shown in Table 5 The data indicated that the isotherm was best represented by the Freundlich isotherm.
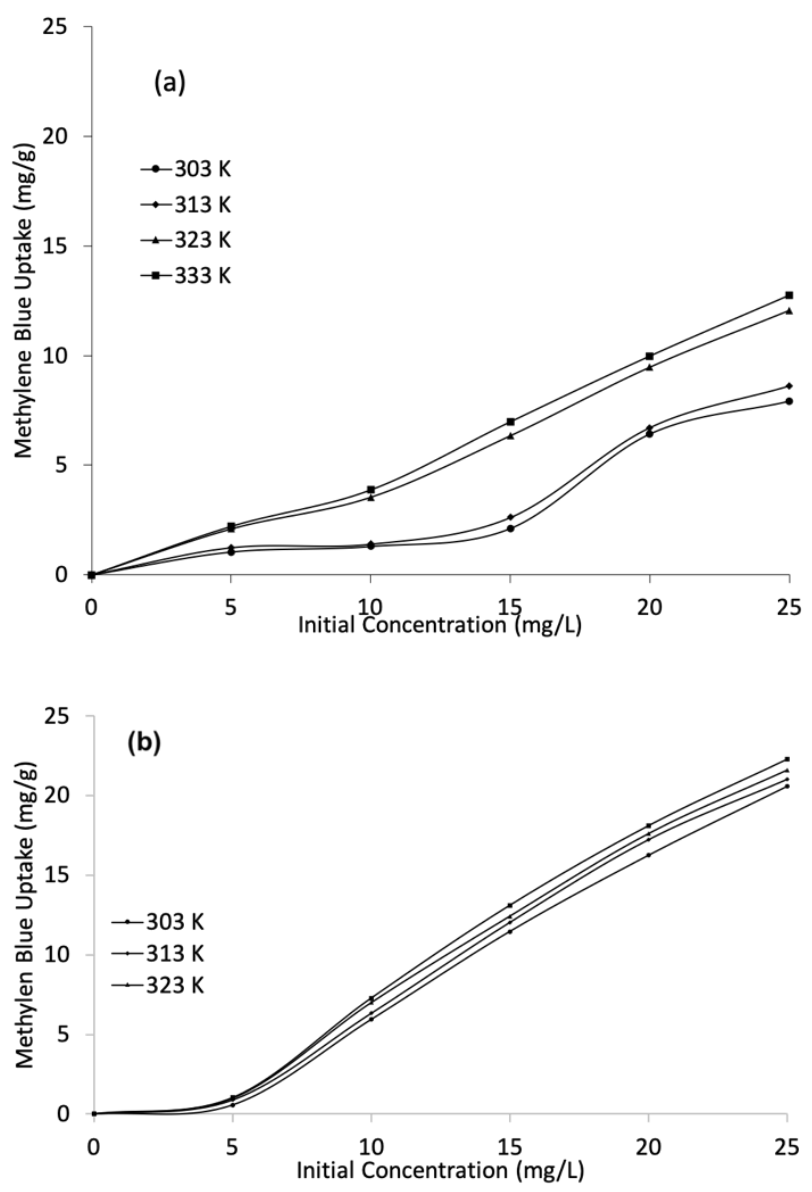

Figure 9: MB uptake by initial concentration at several temperatures by $\mathrm{Mg} / \mathrm{Cr} \mathrm{LDH}$ (a) and intercalated $\mathrm{Mg} / \mathrm{Cr} \mathrm{LDH}$ (b)

The Freundlich isotherm indicates a multilayer adsorption process. Based on the adsorption capacity of $\mathrm{RhB}$ on pristine and modified $\mathrm{Mg} / \mathrm{Cr} \mathrm{LDHs}$, an increase in temperature is correlated with increasing adsorption capacity at equilibrium, as summarized in Table 3. The adsorption data of MB on pristine and modified $\mathrm{Mg} / \mathrm{Cr} \mathrm{LDH}$ is summarized in Table 4. The data indicates that the adsorption using pristine and modified $\mathrm{Mg} / \mathrm{Cr}$ LDHs was best represented by the Freundlich isotherm. The increase in temperature caused the adsorption capacity to be higher at $333 \mathrm{~K}$ than at room temperature. The maximum adsorption capacities for both dyes using modified $\mathrm{Mg} / \mathrm{Cr} \mathrm{LDH}$ were higher than those using pristine $\mathrm{Mg} / \mathrm{Cr} \mathrm{LDH}$. According to Leon et al. [28], the higher content of available carboxylic groups promotes electrostatic interactions between the sorbate and sorbent. The amount of dye adsorbed as a function of temperature is summarized in Tables 5 and 6. The data in Tables 5 and 6 indicate increasing adsorption capacity with increasing temperature in the range of 303-333 K. 
Table 3: Isotherms parameter of adsorption rhodamine $\mathrm{B}$ onto $\mathrm{Mg} / \mathrm{Cr}-\mathrm{LDH}$ and intercalated $\mathrm{Mg} / \mathrm{Cr} \mathrm{LDH}$

\begin{tabular}{|c|c|c|c|c|c|c|}
\hline \multirow{2}{*}{$\mathrm{LDH}$} & \multirow{2}{*}{ adsorption isotherm } & \multirow{2}{*}{ adsorption constant } & \multicolumn{4}{|c|}{$\mathrm{T}(\mathrm{K})$} \\
\hline & & & 303 & 313 & 323 & 333 \\
\hline \multirow{6}{*}{$\mathrm{Mg} / \mathrm{Cr}$} & Langmuir & $\mathrm{Q}_{\max }$ & 20.960 & 27.855 & 28.011 & 32.154 \\
\hline & & $\mathrm{K}_{\mathrm{L}}$ & 0.023 & 0.03 & 0.034 & 0.032 \\
\hline & & $\mathrm{R}^{2}$ & 0.723 & 0.637 & 0.684 & 0.665 \\
\hline & Freundlich & $\mathrm{N}$ & 0.744 & 0.75 & 0.642 & 0.67 \\
\hline & & $\mathrm{K}_{\mathrm{F}}$ & 1.909 & 1.758 & 2.279 & 1.866 \\
\hline & & $\mathrm{R}^{2}$ & 0.947 & 0.866 & 0.914 & 0.896 \\
\hline \multirow[t]{6}{*}{$\mathrm{Mg} / \mathrm{Cr}$ - Oxalate } & Langmuir & $Q_{\max }$ & 74.828 & 77.778 & 120.482 & 139.526 \\
\hline & & $\mathrm{K}_{\mathrm{L}}$ & 0.003 & 0.004 & 0.010 & 0.029 \\
\hline & & $\mathrm{R}^{2}$ & 0.020 & 0.067 & 0.135 & 0.659 \\
\hline & Freundlich & $\mathrm{N}$ & 1.039 & 0.945 & 0.900 & 0.661 \\
\hline & & $\mathrm{K}_{\mathrm{F}}$ & 1.109 & 1.106 & 1.084 & 1.691 \\
\hline & & $\mathrm{R}^{2}$ & 0.930 & 0.962 & 0.912 & 0.913 \\
\hline
\end{tabular}

Table 4: Isotherms parameter of adsorption methylene blue onto $\mathrm{Mg} / \mathrm{Cr}-\mathrm{LDH}$ and intercalated $\mathrm{Mg} / \mathrm{Cr} \mathrm{LDH}$

\begin{tabular}{|c|c|c|c|c|c|c|}
\hline \multirow{2}{*}{$\mathrm{LDH}$} & \multirow{2}{*}{ adsorption isotherm } & \multirow{2}{*}{ adsorption constant } & \multicolumn{4}{|c|}{$\mathrm{T}(\mathrm{K})$} \\
\hline & & & 303 & 313 & 323 & 333 \\
\hline \multirow[t]{6}{*}{$\mathrm{Mg} / \mathrm{Cr}$} & Langmuir & $\mathrm{Q}_{\max }$ & 1.636 & 1.517 & 1.452 & 1.538 \\
\hline & & $\mathrm{K}_{\mathrm{L}}$ & 1.323 & 5.131 & 1.534 & 1.195 \\
\hline & & $\mathrm{R}^{2}$ & 0.926 & 0.955 & 0.938 & 0.964 \\
\hline & Freundlich & $\mathrm{N}$ & 0.446 & 0.497 & 0.572 & 0.629 \\
\hline & & $\mathrm{K}_{\mathrm{F}}$ & 2.912 & 1.625 & 1.142 & 2.160 \\
\hline & & $\mathrm{R}^{2}$ & 0.991 & 0.993 & 0.981 & 0.980 \\
\hline \multirow[t]{6}{*}{$\mathrm{Mg} / \mathrm{Cr}-$ Oxalate } & Langmuir & $\mathrm{Q}_{\max }$ & 8.741 & 4.854 & 2.879 & 2.625 \\
\hline & & $\mathrm{K}_{\mathrm{L}}$ & 0.107 & 0.934 & 0.771 & 0.851 \\
\hline & & $\mathrm{R}^{2}$ & 0.814 & 0.918 & 0.902 & 0.784 \\
\hline & Freundlich & $\mathrm{N}$ & 0.501 & 0.630 & 0.644 & 0.562 \\
\hline & & $\mathrm{K}_{\mathrm{F}}$ & 1.957 & 7.638 & 7.132 & 2.160 \\
\hline & & $\mathrm{R}^{2}$ & 0.961 & 0.938 & 0.877 & 0.981 \\
\hline
\end{tabular}

Table 5: Thermodynamic adsorption parameter of rhodamine B onto $\mathrm{Mg} / \mathrm{Cr}-\mathrm{LDH}$ and intercalated $\mathrm{Mg} / \mathrm{Cr} \mathrm{LDH}$

\begin{tabular}{|c|c|c|c|c|c|c|c|}
\hline $\mathrm{T}(\mathrm{K})$ & $\mathrm{C}$ & $\triangle \mathrm{H}(\mathrm{kJ} / \mathrm{mol})$ & $\triangle \mathrm{S}(\mathrm{kJ} / \mathrm{mol})$ & $\triangle \mathrm{G}(\mathrm{kJ} / \mathrm{mol})$ & $\triangle \mathrm{H}(\mathrm{kJ} / \mathrm{mol})$ & $\triangle \mathrm{S}(\mathrm{kJ} / \mathrm{mol})$ & $\triangle \mathrm{G}(\mathrm{kJ} / \mathrm{mol})$ \\
\hline 303 & & & & -0.362 & & & 0.812 \\
\hline 313 & $10 \mathrm{~mol}$ & 140 & $0 \Omega Q 1$ & -1.171 & 27802 & 000 & -0.081 \\
\hline 323 & $40 \mathrm{mg} / \mathrm{L}$ & 24.100 & 0.081 & -1.981 & 21.883 & 0.089 & -0.975 \\
\hline 333 & & & & -2.790 & & & -1.868 \\
\hline 303 & & & & -1.255 & & & -0.180 \\
\hline 313 & $50 \mathrm{mo} / \mathrm{I}$ & 0601 & 0022 & -1.582 & 26001 & 0000 & -1.076 \\
\hline 323 & $50 \mathrm{mg} / \mathrm{L}$ & 8.681 & 0.033 & -1.910 & 26.981 & 0.090 & -1.973 \\
\hline 333 & & & & -2.238 & & & -2.869 \\
\hline 303 & & & & -1.350 & & & -0.229 \\
\hline 313 & $60 \mathrm{mo} / \mathrm{I}$ & 14581 & & -1.876 & 24427 & 0,091 & -1.043 \\
\hline 323 & $60 \mathrm{mg} / \mathrm{L}$ & 14.584 & 0.053 & -2.401 & 24.431 & 0.081 & -1.857 \\
\hline 333 & & & & -2.927 & & & -2.671 \\
\hline
\end{tabular}

The adsorption process was described by thermodynamic parameters such as Gibbs free energy, enthalpy, and entropy, which can be expressed in a single equation as follows:

$\Delta \mathrm{G}=\Delta \mathrm{H}-T \Delta \mathrm{S}$

where $\Delta \mathrm{G}$ is the change in Gibbs free energy $(\mathrm{kJ} / \mathrm{mol}), \Delta \mathrm{S}$ is the change in entropy $(\mathrm{kJ} / \mathrm{mol})$, and $\Delta \mathrm{H}$ is the change in entropy
$(\mathrm{kJ} / \mathrm{mol})$. The $\Delta \mathrm{H}$ and $\Delta \mathrm{S}$ values were determined from the $\mathrm{y}$ intercept and slope (eq. 3), respectively, as listed in Tables 5 and 6 . The $\Delta \mathrm{S}$ values were positive, which indicated an increase in randomness during the ongoing process. The positive $\Delta \mathrm{H}$ values indicated that the adsorption was endothermic and proceeded via a physisorption process. The likelihood of the adsorption proceeding via a physisorption process was supported by the $\Delta \mathrm{G}$ values which were within the range of $-20-0 \mathrm{~kJ} / \mathrm{mol}$. The negative Gibbs free energy values indicate that the adsorption was 
spontaneous. In addition, the $\Delta \mathrm{H}$ values calculated in this study $(-20 \mathrm{~kJ} / \mathrm{mol})$ are consistent with the hydrogen bond and dipole bond forces of the adsorbent. The adsorption capacities for MB and $\mathrm{RhB}$ in this study are comparable to those of other adsorbents reported in previous literature, which are listed in Table 7.

\begin{tabular}{|c|c|c|c|c|c|c|c|}
\hline $\mathrm{T}(\mathrm{K})$ & $\mathrm{C}$ & $\begin{array}{l}\triangle \mathrm{H} \\
(\mathrm{kJ} / \mathrm{mol})\end{array}$ & $\begin{array}{l}\triangle \mathrm{S} \\
(\mathrm{kJ} / \mathrm{mol})\end{array}$ & $\begin{array}{l}\triangle \mathrm{G} \\
(\mathrm{kJ} / \mathrm{mol})\end{array}$ & $\begin{array}{l}\triangle \mathrm{H} \\
(\mathrm{kJ} / \mathrm{mol})\end{array}$ & $\begin{array}{l}\triangle \mathrm{S} \\
(\mathrm{J} / \mathrm{Kmol})\end{array}$ & $\begin{array}{l}\triangle \mathrm{G} \\
(\mathrm{kJ} / \mathrm{mol})\end{array}$ \\
\hline 303 & \multirow{4}{*}{$20 \mathrm{mg} / \mathrm{L}$} & \multirow{4}{*}{7.198} & 0.031 & -2.145 & \multirow{4}{*}{15.070} & \multirow{4}{*}{0.060} & -2.972 \\
\hline 313 & & & & -2.453 & & & -3.568 \\
\hline 323 & & & & -2.761 & & & -4.163 \\
\hline 333 & & & & -3.070 & & & -4.758 \\
\hline 303 & \multirow{4}{*}{$25 \mathrm{mg} / \mathrm{L}$} & \multirow{4}{*}{22.114} & \multirow{4}{*}{0.081} & -2.581 & \multirow{4}{*}{12.311} & \multirow{4}{*}{0.051} & -3.209 \\
\hline 313 & & & & -3.396 & & & -3.722 \\
\hline 323 & & & & -4.211 & & & -4.234 \\
\hline 333 & & & & -5.026 & & & -4.746 \\
\hline 303 & \multirow{4}{*}{$30 \mathrm{mg} / \mathrm{L}$} & \multirow{4}{*}{5.682} & \multirow{4}{*}{0.032} & -3.871 & \multirow{4}{*}{7.431} & \multirow{4}{*}{0.034} & -2.840 \\
\hline 313 & & & & -4.187 & & & -3.179 \\
\hline 323 & & & & -4.502 & & & -3.518 \\
\hline 333 & & & & -4.817 & & & -3.857 \\
\hline
\end{tabular}

\begin{tabular}{llll}
\multicolumn{5}{c}{ Table 7: Comparison of adsorption capacity of some adsorbents for RhB and MB removal } \\
\hline Dyes & Adsorbent & Adsorption Capacity $(\mathrm{mg} / \mathrm{g})$ & References \\
\hline MB & Ti-Al-Si-O & 162.96 & $(29)$ \\
RhB & Nanocomposite Adsorbent & 142.8 & $(30)$ \\
MB & Nanocomposite SNF/MNP/PS & 103.1 & $(31)$ \\
RhB & Casuarina Equisetifolia Needle (CEN) & 82.34 & $(32)$ \\
RhB & Activated Cotton Stalks (CSAC) & 133.33 & $(33)$ \\
MB & & 153.85 & $(34)$ \\
RhB & Magnetic Lignosulfonate (MLS) & 22.47 & $(35)$ \\
RhB & Magnetic AC/CeO 2 & \\
RhB & Boron Organic Polymers & 324.6 & $(36)$ \\
RhB & Chitosan graft poly & 1,388 & $(37)$ \\
MB & & 556.9 & \\
RhB & SA/HEC/HA Membrane & 936 & $(38)$ \\
MB & & 18.814 & \\
MB & Nanocomposite hydrogel & 20.83 & This work \\
RhB & & 122.5 & This work \\
RhB & MgCr & 62 & This work \\
Mb & & 32.154 & This work \\
RhB & Intercalated MgCr & 1.636 & \\
MB & & 139.526 & \\
\hline
\end{tabular}

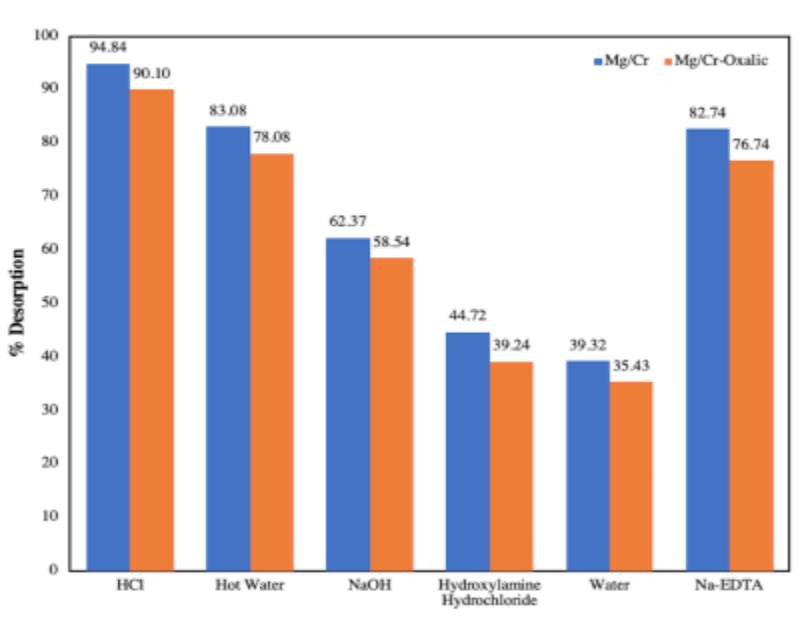

(a)

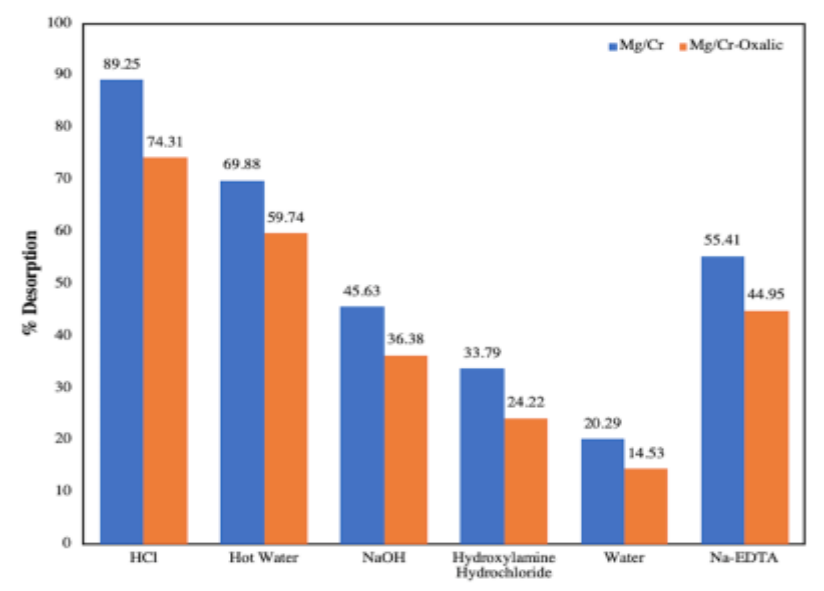

(b)

Figure. 10: Desorption of RhB (a) and MB (b) on $\mathrm{Mg} / \mathrm{Cr}-\mathrm{LDH}$ and on intercalated $\mathrm{Mg} / \mathrm{Cr} \mathrm{LDH}$ 


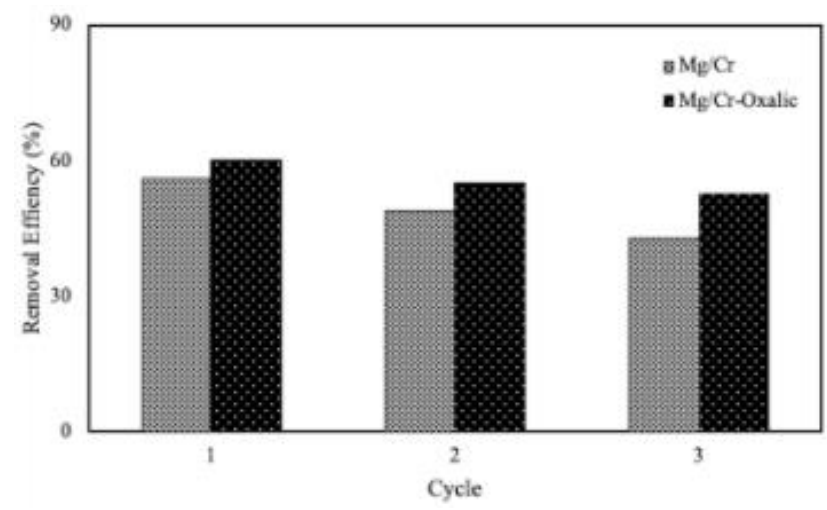

(a)

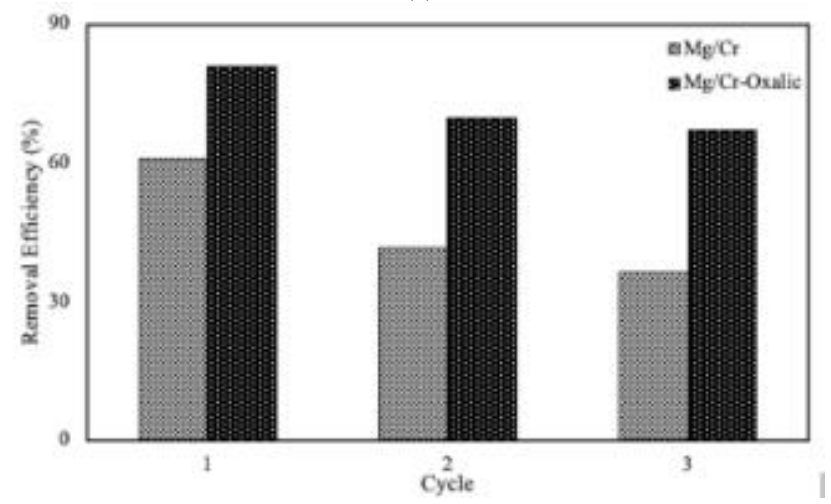

(b)

Figure. 11: Regeneration of $\mathrm{RhB}$ (a) and MB (b) on $\mathrm{MgCr} \mathrm{LDH}$ and on intercalated $\mathrm{Mg} / \mathrm{Cr} \mathrm{LDH}$

The desorption study was conducted in several solvents onto $\mathrm{MgCr}$ and $\mathrm{MgCr}$ modified. Figure 10 shows the y axis is percent desorption using $\mathrm{RhB}$ onto $\mathrm{MgCr}$ and $\mathrm{MgCr}$ modified. As our best acknowledgment, a few the researchers have focused to recovery used material. Several solvent organic, acid, and base were conducted in this treatment for suitable solvents (ie, water, $\mathrm{HCl}, \mathrm{NaOH}, \mathrm{HONH}_{3} \mathrm{Cl}$ and $\mathrm{Na}$-EDTA). The result on Figure 10 shows that the higher desorption is $\mathrm{HCl}$. In this case, $\mathrm{MgCr}$ modified has lower desorption than $\mathrm{MgCr}$ pristine. we assumed that the dye is more trapped in the active site of adsorbents and requires a long time to be desorbed. On the other hand, in acid solution, the hydrotalcite pristine is more desorbed than modified caused the hydrotalcite can be exfoliated (Palapa et al. 2020). The regeneration of $\mathrm{MgCr} \mathrm{LDH}$ and intercalated $\mathrm{MgCr} \mathrm{LDH}$ was investigated by three times cycles. The recycling process of LDHs adsorption-desorption was illustrated in Figure 11. The high effectivity of reuse material showed after intercalated with oxalic anions than pristine. These phenomena caused that LDH pristine can be broken in the acid solution for extended uses. The decreases in removal efficiency from LDH pristine indicated that the structure of LDH is exfoliated and ruined.

\section{Conclusion}

$\mathrm{MgCr}$ and $\mathrm{MgCr}$ intercalated anion oxalate were easily prepared by the ion-exchange method. $\mathrm{MgCr}$ modified anion oxalate has higher adsorbed capacity in equilibrium than pristine amount $\mathrm{MgCr}$ modified anion oxalic has higher adsorption capacity than pristine LDH amount from $32.154 \mathrm{mg}^{-1}$ for pristine $\mathrm{LDH}$ and $139.526 \mathrm{mg} \cdot \mathrm{g}^{-1}$ for intercalated $\mathrm{MgCr} \mathrm{LDH}$ in $\mathrm{RhB}$ dye. The adsorption of both sorbents for $\mathrm{MB}$ and $\mathrm{RhB}$ was classified as physical adsorption with $\Delta \mathrm{H}^{\circ}$ value in the range under $40 \mathrm{~kJ} / \mathrm{mol}$. Moreover, both adsorbents can be reused for further adsorption process. This result based on the desorption results that the $\mathrm{RhB}$ and $\mathrm{MB}$ can be desorbed from the adsorbent as much as $98 \%$.

\section{Acknowledgment}

Author thanks to Ministry of Research Technology and Higher Education Repulic Indonesia Through "Hibah Penelitian Dasar Unggulan Perguruan Tinggi” in Fiscal Year 2019/2020.

\section{Competing interests}

The authors declare that there is no conflict of interest that would prejudice the impartiality of this scientific work.

\section{Authors' contribution}

All authors of this study have a complete contribution for data collection, data analyses and manuscript writing

\section{References}

1. F. Zhang, X. Tang, Y. Huang, A. A. Keller and J. Lan, Competitive removal of $\mathrm{Pb} 2+$ and malachite green from water by magnetic phosphate nanocomposites, Water Res. (2019) 442-451.

2. E. H. Elkhattabi, M. Lakraimi, M. Berraho, A. Legrouri, R. Hammal and L. El Gaini, Acid Green 1 removal from wastewater by layered double hydroxides, Appl. Water Sci. 8 (2018) 1-11.

3. F. A. Dawodu, C. U. Onuh, K. G. Akpomie and E. I. Unuabonah, Synthesis of silver nanoparticle from Vigna unguiculata stem as adsorbent for malachite green in a batch system, SN Appl. Sci. 1 (2019) 1-10.

4. Q. Zhang, Q. Lin, X. Zhang and Y. Chen, A novel hierarchical stiff carbon foam with graphene-like nanosheet surface as the desired adsorbent for malachite green removal from wastewater, Environ. Res. 179 (2019) 108746.

5. S. Boubakri, M. A. Djebbi, Z. Bouaziz, P. Namour, N. JaffrezicRenault, A. B. H. Amara, M. Trabelsi-Ayadi, I. Ghorbel-Abid and R. Kalfat, Removal of two anionic reactive textile dyes by adsorption into $\mathrm{MgAl}$-layered double hydroxide in aqueous solutions, Environ. Sci. Pollut. Res. 25 (2018) 23817-23832.

6. Y. Lu, B. Jiang, L. Fang, F. Ling, J. Gao, F. Wu and X. Zhang, High performance $\mathrm{NiFe}$ layered double hydroxide for methyl orange dye and $\mathrm{Cr}(\mathrm{VI})$ adsorption, Chemosphere 152 (2016) 415-422.

7. F. Mohamed, M. R. Abukhadra and M. Shaban, Removal of safranin dye from water using polypyrrole nanofiber/Zn-Fe layered double hydroxide nanocomposite (Ppy NF/Zn-Fe LDH) of enhanced adsorption and photocatalytic properties, Sci. Total Environ. 640-641 (2018) 352-363.

8. S. Mallakpour and M. Hatami, An effective, low-cost and recyclable bio-adsorbent having amino acid intercalated LDH@Fe3O4/PVA magnetic nanocomposites for removal of methyl orange from aqueous solution, Appl. Clay Sci. 174 (2019) 127-137.

9. T. Taher, D. Rohendi, R. Mohadi and A. Lesbani, Thermal Activated of Indonesian Bentonite as A Low-Cost Adsorbent for Procion Red Removal from Aqueous Solution, J. Pure Appl. Chem. Res. 7 (2018) 79-93.

10. H. Zhou, Z. Jiang and S. Wei, A new hydrotalcite-like absorbent $\mathrm{FeMnMg}-\mathrm{LDH}$ and its adsorption capacity for $\mathrm{Pb} 2+$ ions in water, Appl. Clay Sci. 153 (2018) 29-37.

11. I. Harizi, D. Chebli, A. Bouguettoucha, S. Rohani and A. Amrane, A New $\mathrm{Mg}-\mathrm{Al}-\mathrm{Cu}-\mathrm{Fe}-\mathrm{LDH}$ Composite to Enhance the Adsorption of 
Acid Red 66 Dye: Characterization, Kinetics and Isotherm Analysis, Arab. J. Sci. Eng. 44 (2019) 5245-5261.

12. K. Abdellaoui, I. Pavlovic, M. Bouhent, A. Benhamou and C. Barriga, A comparative study of the amaranth azo dye adsorption/desorption from aqueous solutions by layered double hydroxides, Appl. Clay Sci. 143 (2017) 142-150.

13. S. Yanming, L. Dongbin, L. Shifeng, F. Lihui, C. Shuai and M. A. Haque, Removal of lead from aqueous solution on glutamate intercalated layered double hydroxide, Arab. J. Chem. 10 (2017) S2295-S2301.

14. M. Xu, B. Bi, B. Xu, Z. Sun and L. Xu, Polyoxometalate-intercalated $\mathrm{ZnAlFe}$-layered double hydroxides for adsorbing removal and photocatalytic degradation of cationic dye, Appl. Clay Sci. 157 (2018) 86-91.

15. T. Kameda, H. Takeuchi and T. Yoshioka, NiAl layered double hydroxides modified with citrate, malate, and tartrate: Preparation by coprecipitation and uptake of $\mathrm{Cu} 2$ from aqueous solution, J. Phys. Chem. Solids 72 (2011) 846-851.

16. A. Lesbani, D. R. Maretha, T. Taher, Miksusanti, R. Mohadi and R. Andreas, Layered double hydroxides $\mathrm{Mg} / \mathrm{Fe}$ intercalated $\mathrm{H} 3[\alpha-$ PW12O40]- n H2O as adsorbent of cadmium(II), AIP Conf. Proc. 2049 (2018).

17. O. Mrózek, P. Ecorchard, P. Vomáčka, J. Ederer, D. Smržová, M. Š. Slušná, A. Machálková, M. Nevoralová and H. Beneš, Mg-Al-La LDH-MnFe2O4 hybrid material for facile removal of anionic dyes from aqueous solutions, Appl. Clay Sci. 169 (2019) 1-9.

18. S. Yu, X. Wang, Z. Chen, J. Wang, S. Wang, T. Hayat and X. Wang, Layered double hydroxide intercalated with aromatic acid anions for the efficient capture of aniline from aqueous solution, J. Hazard. Mater. 321 (2017) 111-120.

19. N. R. Palapa, Y. Saria, T. Taher, R. Mohadi and A. Lesbani, Synthesis and Characterization of $\mathrm{Zn} / \mathrm{Al}, \mathrm{Zn} / \mathrm{Fe}$, and $\mathrm{Zn} / \mathrm{Cr}$ Layered Double Hydroxides: Effect of M3+ ions Toward Layer Formation, Sci. Technol. Indones. 4 (2019) 36-39.

20. H. Starukh and S. Levytska, The simultaneous anionic and cationic dyes removal with $\mathrm{Zn}-\mathrm{Al}$ layered double hydroxides, Appl. Clay Sci. 180 (2019) 0-5.

21. M. Shafigh, M. Hamidpour and G. Furrer, Zinc release from Zn-Mg$\mathrm{Fe}(\mathrm{III})-\mathrm{LDH}$ intercalated with nitrate, phosphate and carbonate: The effects of low molecular weight organic acids, Appl. Clay Sci. 170 (2019) 135-142.

22. M. N. Sepehr, T. J. Al-Musawi, E. Ghahramani, H. Kazemian and M. Zarrabi, Adsorption Performance of Magnesium/Aluminum Layered Double Hydroxide Nanoparticles for Metronidazole From Aqueous Solution, Arab. J. Chem. 10 (2017) 611-623.

23. R. M. M. dos Santos, R. G. L. Gonçalves, V. R. L. Constantino, C. V. Santilli, P. D. Borges, J. Tronto and F. G. Pinto, Adsorption of Acid Yellow 42 dye on calcined layered double hydroxide: Effect of time, concentration, pH and temperature, Appl. Clay Sci. 140 (2017) 132139.

24. L. Deng, H. Zeng, Z. Shi, W. Zhang and J. Luo, Sodium dodecyl sulfate intercalated and acrylamide anchored layered double hydroxides: A multifunctional adsorbent for highly efficient removal of Congo red, J. Colloid Interface Sci. 521 (2018) 172-182.
25. Y. Li, H. Y. Bi, Y. Q. Liang, X. M. Mao and H. Li, A magnetic coreshell dodecyl sulfate intercalated layered double hydroxide nanocomposite for the adsorption of cationic and anionic organic dyes, Appl. Clay Sci. 183 (2019) 105309.

26. M. Oktriyanti, N. R. Palapa, R. Mohadi and A. Lesbani, Indonesian Journal of Environmental Management and Sustainability Modification Of $\mathrm{Zn}-\mathrm{Cr}$ Layered Double Hydroxide With Keggin Ion, Indones. J. Environ. Manag. Sustain. 3 (2019) 93-99.

27. E. Coronado, C. Martí-Gastaldo, E. Navarro-Moratalla and A. Ribera, Intercalation of [M(ox)3]3- $(\mathrm{M}=\mathrm{Cr}, \mathrm{Rh})$ complexes into NiIIFeIIILDH, Appl. Clay Sci. 48 (2010) 228-234.

28. O. León, A. Muñoz-Bonilla, D. Soto, D. Pérez, M. Rangel, M. Colina and M. Fernández-García, Removal of anionic and cationic dyes with bioadsorbent oxidized chitosans, Carbohydr. Polym. 194 (2018) 375-383.

29. U. Pal, A. Sandoval, S. I. U. Madrid, G. Corro, V. Sharma and P. Mohanty, Mixed titanium, silicon, and aluminum oxide nanostructures as novel adsorbent for removal of rhodamine $6 \mathrm{G}$ and methylene blue as cationic dyes from aqueous solution, Chemosphere 163 (2016) 142-152.

30. M. I. Mohammed and S. Baytak, Synthesis of Bentonite-Carbon Nanotube Nanocomposite and Its Adsorption of Rhodamine Dye From Water, Arab. J. Sci. Eng. 41 (2016) 4775-4785.

31. Z. Li, X. Tang, K. Liu, J. Huang, Q. Peng, M. Ao and Z. Huang, Fabrication of novel sandwich nanocomposite as an efficient and regenerable adsorbent for methylene blue and $\mathrm{Pb}$ (II) ion removal, $J$. Environ. Manage. 218 (2018) 363-373.

32. M. R. R. Kooh, M. K. Dahri and L. B. L. Lim, The removal of rhodamine B dye from aqueous solution using Casuarina equisetifolia needles as adsorbent, Cogent Environ. Sci. 2 (2016) 1-14.

33. M. Özdemir, Ö. Durmuş, Ö. Şahin and C. Saka, Removal of methylene blue, methyl violet, rhodamine B, alizarin red, and bromocresol green dyes from aqueous solutions on activated cotton stalks, Desalin. Water Treat. 57 (2016) 18038-18048.

34. J. Geng, F. Gu and J. Chang, Fabrication of magnetic lignosulfonate using ultrasonic-assisted in situ synthesis for efficient removal of $\mathrm{Cr}(\mathrm{VI})$ and Rhodamine B from wastewater, J. Hazard. Mater. 375 (2019) 174-181.

35. M. Tuzen, A. Sarı and T. A. Saleh, Response surface optimization, kinetic and thermodynamic studies for effective removal of rhodamine $\mathrm{B}$ by magnetic $\mathrm{AC} / \mathrm{CeO} 2$ nanocomposite, J. Environ. Manage. 206 (2018) 170-177.

36. Y. Tang, T. He, Y. Liu, B. Zhou, R. Yang and L. Zhu, Sorption behavior of methylene blue and rhodamine B mixed dyes onto chitosan graft poly (acrylic acid-co-2-acrylamide-2-methyl propane sulfonic acid) hydrogel, Adv. Polym. Technol. 37 (2018) 2568-2578.

37. S. S. Shenvi, A. M. Isloor, A. F. Ismail, S. J. Shilton and A. Al Ahmed, Humic Acid Based Biopolymeric Membrane for Effective Removal of Methylene Blue and Rhodamine B, Ind. Eng. Chem. Res. 54 (2015) 4965-4975.

38. K. Soleimani, A. D. D. Tehrani and M. Adeli, Bioconjugated graphene oxide hydrogel as an effective adsorbent for cationic dyes removal, Ecotoxicol. Environ. Saf. 147 (2018) 34-42. 